\title{
Developmental defects in pelagic fish embryos from the western Baltic
}

\author{
H. v. Westernhagen ${ }^{1}$, V. Dethlefsen ${ }^{2}$, P. Cameron ${ }^{2}$, \\ J. Berg ${ }^{2} \&$ G. Fürstenberg ${ }^{1}$ \\ ${ }^{1}$ Biologische Anstalt Helgoland (Zentrale), D-2000 Hamburg 52 \\ ${ }^{2}$ Institut für Küsten- und Binnenfischerei der Bundesforschungsanstalt für Fischerei, \\ Außenstelle Cuxhaven, D-2190 Cuxhaven
}

\begin{abstract}
In February/March 1983 and 1984 a survey of pelagic fish eggs was conducted in the western Baltic (Kiel Bight), employing a horizontally towed plankton net $(1 \mathrm{~m} \varnothing$ and $300 \mu \mathrm{m} \mathrm{mesh})$. Maximum egg numbers in the upper meter of the $S=21 \times 10^{-3}$ salinity layer were $200 \cdot 100 \mathrm{~m}^{-3}$. The most abundant eggs were cod (up to $142 \mathrm{eggs} \cdot 100 \mathrm{~m}^{-3}$ ), followed by plaice (up to $74 \mathrm{eggs} \cdot 100 \mathrm{~m}^{-3}$ ) and flounder ( 20 eggs $\cdot 100 \mathrm{~m}^{-3}$ ). A considerable percentage of embryos of all species displayed aberrant development. In $198318 \%$ of cod, $22 \%$ of flounder and $24 \%$ of plaice eggs caught contained defective embryos; in 1984 this number was larger, ranging from $28 \%$ in plaice over $32 \%$ in cod to $44 \%$ in flounder. Early developmental stages showed the highest malformation rates (up to $51 \%$ in the case of eariy flounder embryos). With progressive development, malformations decreased in numbers, being lowest prior to hatching. Highest rates of malformations were recorded in the Mecklenburg Bight in 1983. A second area with high incidence of malformation rates was located south and east of the island of Langeland. Several reasons, including environmental and anthropogenic factors, for the occurrence of malformed embryos in pelagic fish eggs are discussed. The potential of malformation rates in embryos of pelagic fish eggs as a tool for monitoring is considered.
\end{abstract}

\section{INTRODUCTION}

Impairment of reproduction for whatever reason must be considered an alarm signal of utmost concern for an affected species. It may eventually lead to the extinction of a population or even of a species. This has been demonstrated for birds of prey and marine birds in the late 1960s and early 1970s in North America and Europe (Peakall, 1970; Ratcliffe, 1970), as a result of the widespread use of DDT.

Examples of the consequences of reproductive impairment in fishes include their large-scale disappearance from acidified lakes in southern Norway and North America (Sevaldrud et al., 1980; Beamish \& Harvey, 1972; Harvey \& Lee, 1982; Haines, 1981), reduced fecundity through the effects of DDT accumulation on lake trout (Salvelinus namaykush, Burdick et al, 1964) and spotted sea trout (Cynoscion nebulosus, Burdick et al., 1972), as well as the overall decline in the striped bass population (Morone saxatilis) in San Francisco Bay (Whipple et al., 1981).

There are various reasons for reproductive failure in aquatic organisms (cf. Westernhagen, 1988), many of them closely associated with man-made pollution. For teleosts this 
has been demonstrated with eggs from field specimen incubated in the laboratory (Westernhagen et al., 1981; Hansen et al., 1985; Spies et al., 1985). Wild parental fish with a high body burden of chlorinated hydrocarbons produced eggs which, after artificial insemination, yielded lower viable hatches than less contaminated eggs. For example, at greater gonad PCB-burdens of $120 \mathrm{ng} \mathrm{g}^{-1}$ (wet wt.), the viable hatch dropped to below $50 \%$ in eggs of flounder and herring. In starry flounder (Spies et al., 1985), this level was around $200 \mathrm{ng} \mathrm{g}^{-1}$ for gonads. Among eggs that died in early stages of development a large percentage of embryos displayed developmental aberrations before death finally occurred.

On the basis of these findings one also would expect to detect deleterious effects of contamination in naturally spawned eggs in the field. Acutely lethal effects resulting in immediate death of the embryo would eliminate such eggs from the planktonic community as dead eggs do not float. However one would expect to catch eggs exhibiting chronic sublethal effects, resulting in defective embryonic development, before they ultimately die.

First reports of unusual mortality of pelagic fish eggs in polluted areas came from the investigations of Dannevig (1945) in the Oslofjord. Recently, Longwell \& Hughes (1981) also found high malformation rates as well as mitotic abnormalities in mackerel eggs from the polluted New York Bight. Dethlefsen et al. (1985) and Graumann (1986) made similar observations on the frequent occurrence of defective fish embryos in pelagic eggs from the southern North Sea and the central and eastern Baltic. The present investigation on developmental defects in embryos of pelagic fish eggs was conducted in the western Baltic, where flounders for the study conducted by Westernhagen et al. (1981) had been caught, yielding eggs of which a high percentage produced non-viable larvae.

The aim of the present study was to establish the incidence of naturally spawned fish eggs with developmental abnormalities, and to evaluate this criterion for its use as a biological effects monitoring tool.

\section{MATERIAL AND METHODS}

\section{Catching procedure}

In February/March 1983 and 1984, pelagic fish eggs were caught in the western Baltic by the RV "Friedrich Heincke" using a horizontally towed plankton net $(1 \mathrm{~m} \varnothing$, $300 \mu \mathrm{m}$ mesh). The net was towed horizontally for $10 \mathrm{~min}$ at a predetermined depth and at a speed of $<1 \mathrm{kn}$, since high towing speeds of $4 \mathrm{kn}$ or more are known to cause up to $92 \%$ egg mortality (Southward \& Demir, 1974). Towing depths were chosen according to salinity using data provided by Strodtmann (1906), Kändler (1949), Kändler \& Tan (1965), and information on the buoyancy of pelagic gadoid and flatfish eggs in the Baltic given by Westernhagen (1970). As was confirmed experimentally with newly fertilized cod eggs from the western Baltic, a salinity of $21 \times 10^{-3}$, irrespective of temperature, had a high enough density for the majority of the eggs to float. Tows below or above this theoretically determined buoyancy level yielded only insignificant numbers of eggs confirming that towing depths had been correctly identified. The net was towed in the upper stratum of the $S=21 \times 10^{-3}$ layer, which, depending on station hydrography (cf. Kändler, 1956; Siedler \& Hatje, 1974), normally was between 5 and $15 \mathrm{~m}$ deep. However, 
at certain stations it was necessary to tow the net directly above the bottom because of limited depth. Actual towing depth varied $\pm 3 \mathrm{~m}$ from the theoretically determined value.

At several stations (cf. Siedler \& Hatje, 1974), salinity did not reach S $=21 \times 10^{-3}$ even at the bottom. Yet the operation of the plankton net close to the bottom also yielded eggs at these stations. Thus fish eggs were found to be buoyant down to a salinity of $17.5 \times 10^{-3}$ at a temperature of $1.0^{\circ} \mathrm{C}$ (Sigma $\left.\mathrm{T}=14.9\right)$.

Temperature at the towing depth varied between 0.8 and $2.9^{\circ} \mathrm{C}$ (see Siedler \& Hatje, 1974). Immediately after hauling in the catch, which was concentrated in $500 \mathrm{ml}$ of water in the end of the net (plankton beaker), it was poured into a 3-1 glass vessel containing $1.5 \mathrm{l}$ of temperated seawater at $\mathrm{S}=25 \times 10^{-3}$. After the catch had been added, the final salinity was about $22-23 \times 10^{-3}$ which allowed all eggs to rise to the surface, where they were sorted for microscopic analysis.

\section{Microscopic analysis}

Eggs were examined under a stereo-microscope at 16 and 32 magnifications. Stages of development (Ia-IV) were determined according to Westernhagen (1970), and are characterized briefly in the following.

Ia: Early cleavages and blastodisc;

Ib: Gastrulation, epiboly;

II: Embryo up to $180^{\circ}$ around yolk, head formed;

III: Embryo between $180^{\circ}-270^{\circ}$ around yolk, heart beat, primordial fins present ${ }_{i}$

IV: Embryo between $270^{\circ}-360^{\circ}$ around yolk, tail free, eye pigmentation, body movements.

Existing species specific differences in developmental patterns are described in detail by Westernhagen et al. (1970).

Development was considered defective, if stages (Ia-IV) deviated from normal development and morphological differentiation. Gross abnormalities are shown in Figure 1 for several stages of flounder and cod eggs. More subtle abnormalities including irregular first cleavages (Fig. 1a-b), gastrulae with loose cell aggregates (Fig. 1c-e), blister-like outcrops from body axis (Fig. 1f-g), bent notochords and minor aberrations such as inclusions in early cells or separate cell-aggregates in the yolk-sac membrane (Fig. $1 \mathrm{~h}-\mathrm{i}$ ) were also considered as examples of abnormal development.

\section{Survival experiments}

To investigate the relevance of malformations regarding embryo survival, incubation experiments with batches of eggs from the respective catches were conducted to determine the viable hatch. For this purpose, eggs were incubated in $300 \mathrm{~cm}^{3}$ of seawater at $5^{\circ} \mathrm{C}$ and $\mathrm{S}=25 \times 10^{-3}$. Incubation medium was North Sea water $\left(\mathrm{S}=33 \times 10^{-3}\right)$ diluted with Baltic sea water of $S=15 \times 10^{-3}$ to provide $S=25 \times 10^{-3}$. Dead embryos or larvae were removed daily. After hatching was completed, viable hatch $(\%)$ was calculated for the different species. 

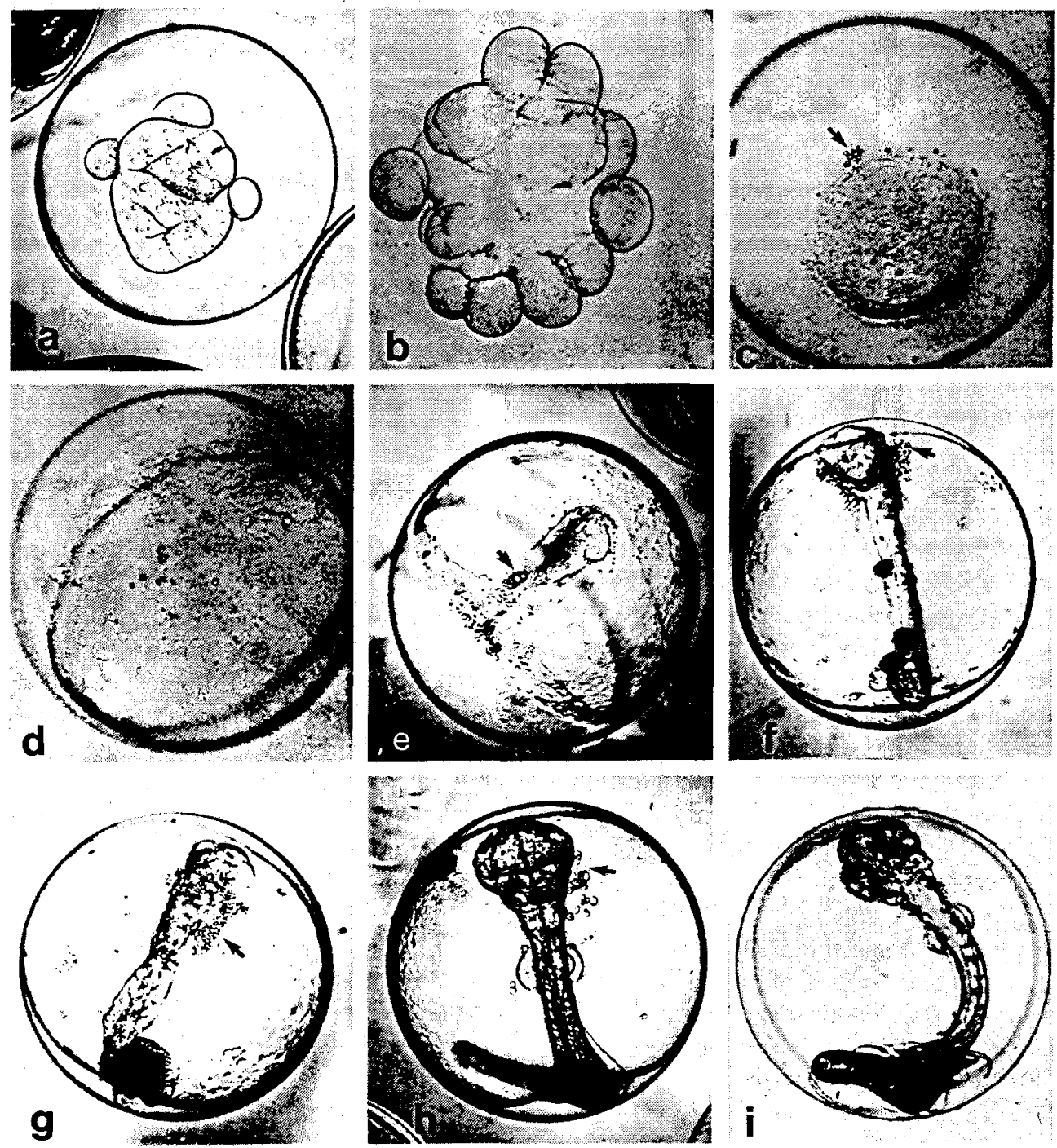

Fig. 1. Abnormal development of pelagic fish eggs from the western Baltic February/March 1983 and 1984. a-b: irregular first cleavages; c-e: gastrulae with loose cell aggregates; $f-g$ : blister-like outcrops from body axis; $\mathrm{h}-\mathrm{i}$ : embryos with bent notochord and cell aggregates on yolk-membrane.

Arrows indicate abnormal cell proliferations

\section{Evaluation of data}

For evaluation of the field distribution of malformations, a control chart in the form of Duncan's stabilized $p$-chart was used. The mean relative frequency $\left(p^{\prime}\right)$ of malformations was obtained for a particular item at all cruise stations. That is, the weighted mean of the 
frequencies at all stations served as the central line of the chart. The differences (D) of the total relative frequencies ( $p_{i}$ to $p^{\prime}$ ) were calculated for the stations and expressed in standard deviations, considering the item's actual abundance $\left(\mathrm{n}_{\mathrm{i}}\right)$ at each station, using the formula:

$$
D=\frac{p_{i}-p^{\prime}}{\sqrt{p^{\prime}\left(1-p^{\prime}\right) / n_{i}}} .
$$

When the resulting difference was beyond the sigma-limit, the station was marked with a symbol (triangle or hexagon), half the height of which was representative of the number of standard deviations it differed from the overall mean rate of all stations. $D$ was calculated only for those stations for which $n_{i}$ exceeded 20 . This method of display demonstrates the significance of the deviations from the mean rate observed.

\section{RESULTS}

\section{Buoyancy and distribution of eggs}

The vertical distribution of eggs, as determined by number of eggs in catches from different salinity strata, confirmed that most eggs floated in water with a sigma $T$ value of at least 17.6 (corresponding to $S=21 \times 10^{-3}, 5^{\circ} \mathrm{C}$ ) at varying depths, depending on the location of the $21 \times 10^{-3}$ layer. Since the salinity of surface waters in the Baltic decreases towards the east, the $21 \times 10^{-3}$ layer - and consequently the pelagic eggs - sank progressively deeper, eventually reaching the bottom as described by Hensen (1884). In February 1983, no pelagic eggs were caught east of $12^{\circ} 00^{\prime} \mathrm{E}$ due to low salinity. In February 1984, low salinity prevented the occurrence of pelagic eggs east of $11^{\circ} 30^{\prime} \mathrm{E}$.

Overall egg density in the $21 \times 10^{-3}$ layer is depicted in Figures 2 and 5 for February/ March 1983 and 1984. During the period of the cruise (mid February until beginning of March) in both years cod eggs were the most abundant (Figs 3,6 ), while plaice eggs were second (Figs 4,7). Flounder eggs were found only in small numbers, not more than 4 eggs $100 \mathrm{~m}^{-3}$ along $54^{\circ} 40^{\prime} \mathrm{N}$ latitude in 1984 , and up to 20 eggs $\cdot 100 \mathrm{~m}^{-3}$ south of Aerö in 1983.

\section{Egg densities and species abundance}

Overall egg densities were highest in the central western Baltic (Figs 2, 5) with maximum numbers of about 200 eggs $100 \mathrm{~m}^{-3}$ in both years in the same area $\left(54^{\circ} 40^{\prime} \mathrm{N}\right.$; $10^{\circ} 25^{\prime} \mathrm{E}$ ). Comparing 1983 and 1984, it is evident that overall egg numbers in 1983 were higher throughout the total area of the western Baltic, including large parts of the Bight of Mecklenburg. In 1983, 50 and 100 eggs $\cdot 100 \mathrm{~m}^{-3}$ were found throughout almost the entire western Baltic basin while in 1984 the area with $>50$ eggs $\cdot 100 \mathrm{~m}^{-3}$ was considerably smaller.

During both years $(1983,1984)$, eggs of 4 species were caught: cod (Gadus morhua), plaice (Pleuronectes platessa), flounder (Platichthys flesus) and fourbeard rockling (Onos cimbrius). Rockling eggs occurred only sporadically and were excluded from evaluation. Total numbers of eggs caught during the cruises are given in Table 1. Cod eggs were dominant in February/March 1983 and 1984, followed in abundance by plaice and 


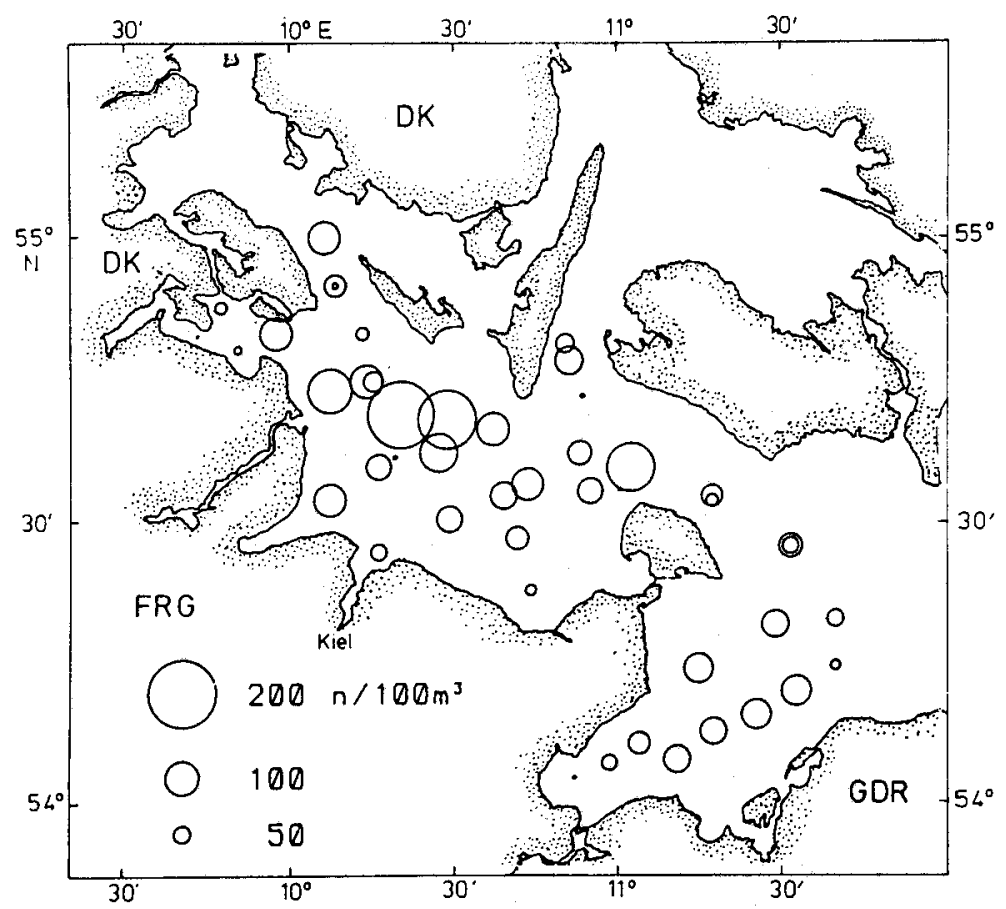

Fig. 2. Overall egg density in the $S=21 \times 10^{-3}$ layer in the western Baltic (1983) as number of eggs per $100 \mathrm{~m}^{3}$

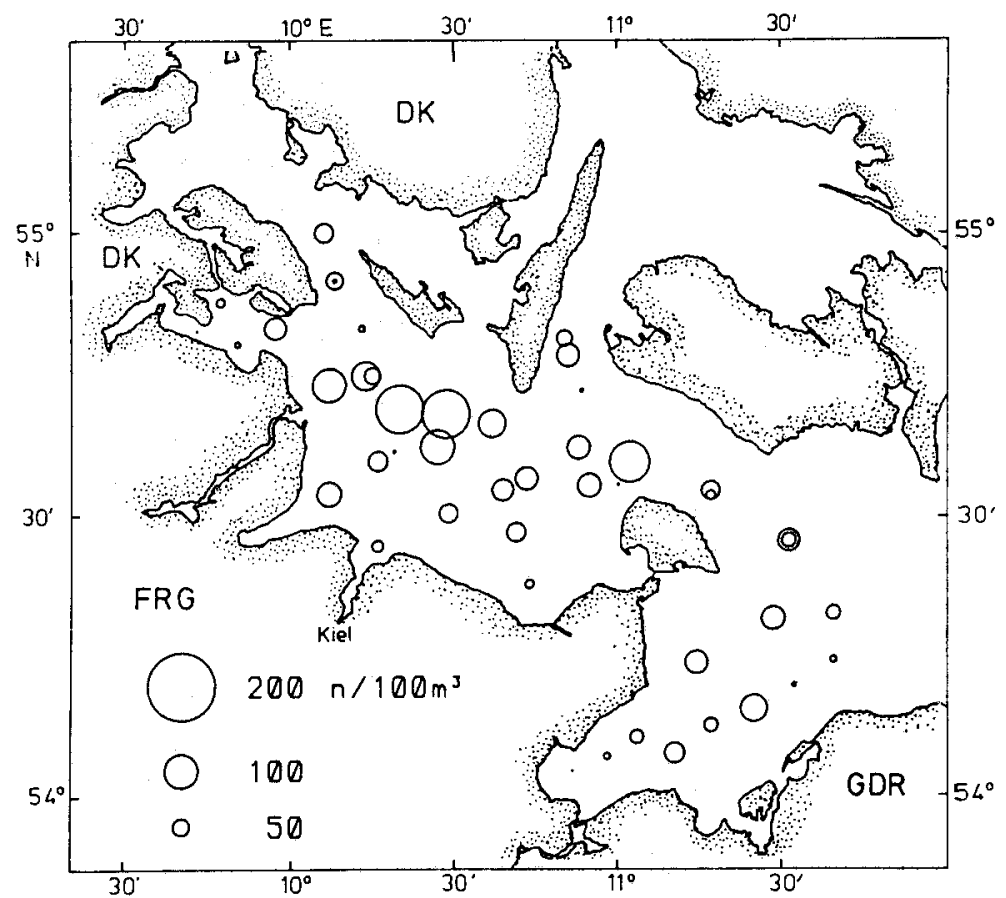

Fig. 3. Density and distribution of cod eggs in the $S=21 \times 10^{-3}$ layer in the western Baltic (1983) as number of eggs per $100 \mathrm{~m}^{3}$ 


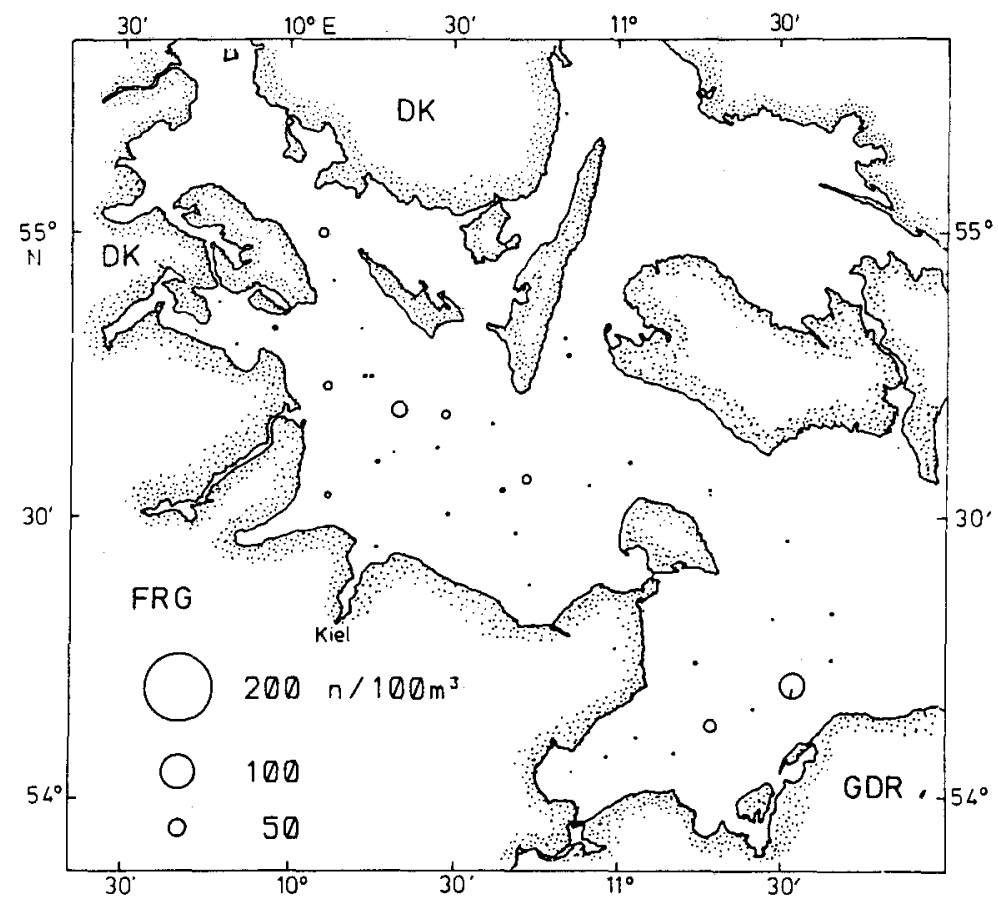

Fig. 4. Density and distribution of plaice eggs in the $S=21 \times 10^{-3}$ layer in the western Baltic (1983) as number of eggs per $100 \mathrm{~m}^{3}$

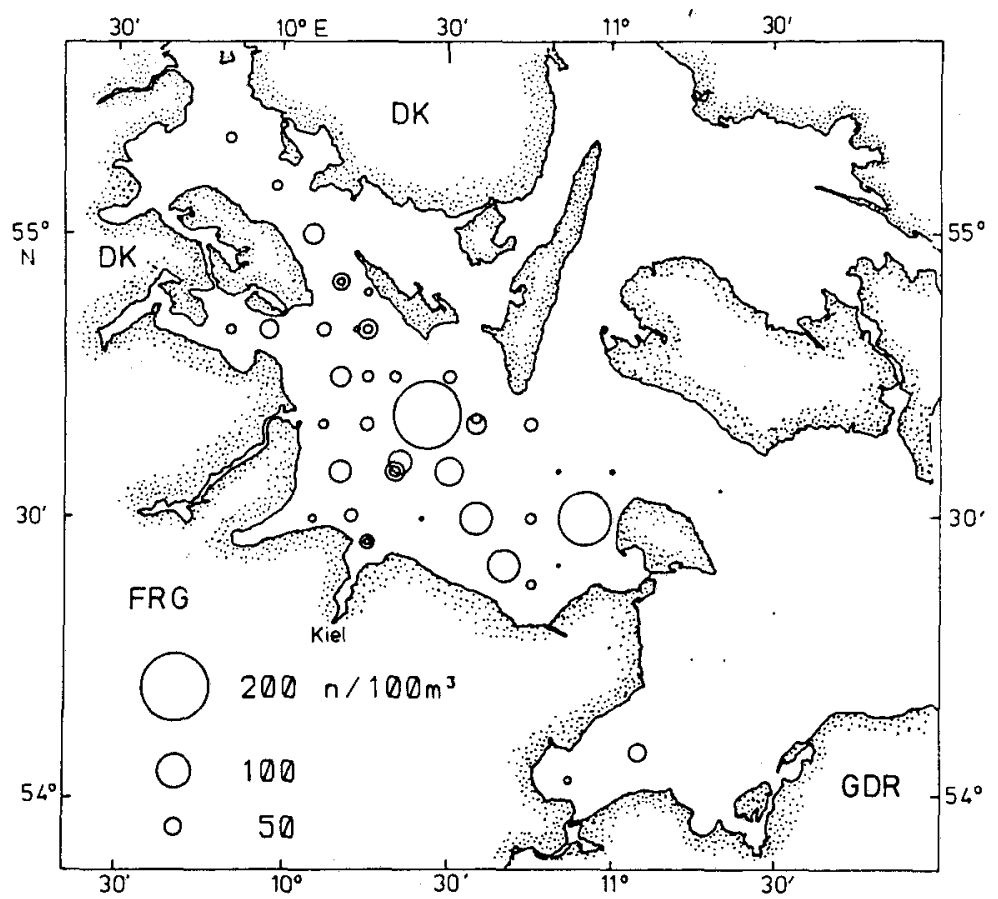

Fig. 5. Overall egg density in the $S=21 \times 10^{-3}$ layer in the western Baltic (1984) as number of eggs per $100 \mathrm{~m}^{3}$ 


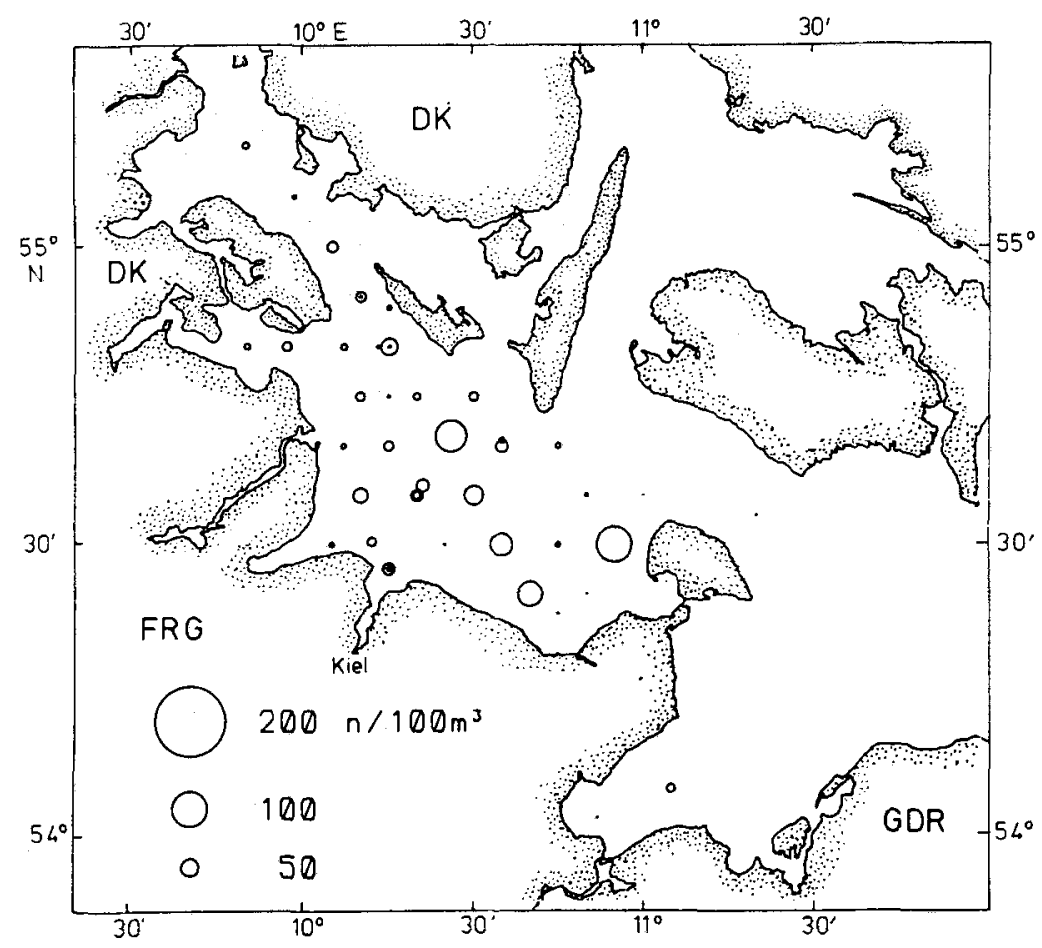

Fig. 6. Density and distribution of cod eggs in the $S=21 \times 10^{-3}$ layer in the western Baltic (1984) as numbers per $100 \mathrm{~m}^{3}$

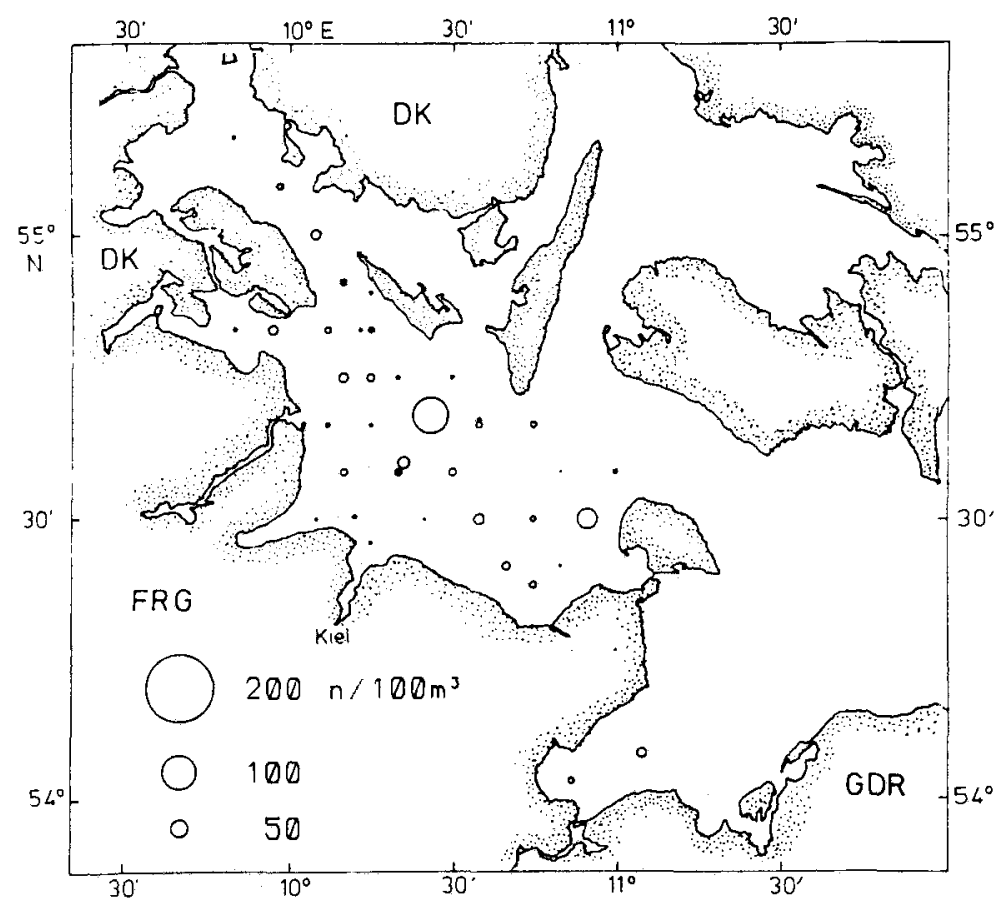

Fig. 7. Density and distribution of plaice eggs in the $S=21 \times 10^{-3}$ layer in the western Baltic (1984) as numbers per $100 \mathrm{~m}^{3}$ 
Table 1. Total number ( $\mathrm{n}$ ) and number of defective (def) embryos of pelagic fish eggs in the $\mathrm{S}=21 \times$ $10^{-3}$ layer in the western Baltic. 1983: 50 stations; 1984: 56 stations. $\mathrm{n}=$ total number

\begin{tabular}{|lrrrrrr|}
\hline Species & $\mathrm{n}$ & $\begin{array}{c}1983 \\
\text { def }\end{array}$ & $\%$ & $\mathrm{n}$ & $\begin{array}{c}1984 \\
\text { def }\end{array}$ & $\%$ \\
\hline Cod & 21142 & 3869 & 18.3 & 9336 & 2978 & 31.9 \\
Plaice & 3484 & 833 & 23.9 & 6788 & 1921 & 28.3 \\
Flounder & 2509 & 557 & 22.2 & 288 & 128 & 44.4 \\
Total & 27135 & 5264 & 19.4 & 16412 & 5022 & 30.6 \\
\hline
\end{tabular}

flounder. Seventy-eight percent of all eggs caught in 1983, and $57 \%$ in 1984, were cod. The distribution of eggs of the three species is depicted in Figures 3,4,6 and 7. Cod eggs were most abundant in the centre of the western Baltic and west of the island of Fehmarn (Figs 3,6). Plaice eggs in 1984 were most abundant in the same area but in 1983 they occurred in highest numbers in the Mecklenburger Bucht (Figs 4, 7). Occurrence of flounder eggs in the western Baltic generally was low with small centres of 20 eggs $100 \mathrm{~m}^{-3}$ in the Mecklenburger Bucht and between the islands of Als and Aerö (Denmark).

Most of the cod eggs were in early developmental stages, the majority being in stage Ia (Table 2) (for stage definition see Westernhagen, 1970). With regard to plaice, there was a preponderance in 1984 of older developmental stages and in 1983 these stages occurred in relatively high abundance. For flounder, the,information from the plankton catches regarding state of spawning season was somewhat ambiguous, with a high number of old (stage III) flounder eggs in 1983, and 1984 stage Ia as the most abundant. In 1984, data on the occurrence of flounder eggs was so meagre that they did not provide a data base large enough for further analysis.

Table 2. Occurrence of pelagic fish eggs at different developmental stages in the western Baltic in February/March 1983 and 1984. For definition of stages see 'Materials and Methods' and Westernhagen (1970). $\mathrm{n}=$ total number; $\%$ def $=\%$ defective embryos

\begin{tabular}{|c|c|c|c|c|c|c|c|c|c|c|}
\hline Stage & $\begin{array}{l}\mathrm{Ia} \\
\mathrm{n}\end{array}$ & $\begin{array}{c}\% \\
\text { def }\end{array}$ & $\begin{array}{c}\text { Ib } \\
\text { n }\end{array}$ & $\begin{array}{c}\% \\
\text { def }\end{array}$ & $\begin{array}{l}\text { II } \\
\mathrm{n}\end{array}$ & $\begin{array}{c}\% \\
\text { def }\end{array}$ & $\frac{\mathrm{III}}{\mathrm{n}}$ & $\begin{array}{c}\% \\
\text { def }\end{array}$ & $\begin{array}{c}\text { IV } \\
\text { n }\end{array}$ & $\begin{array}{c}\% \\
\text { def }\end{array}$ \\
\hline \multicolumn{11}{|c|}{1983} \\
\hline Cod & 11435 & 22.0 & 4485 & 15.9 & 2852 & 12.1 & 2068 & 14.5 & 302 & 2.6 \\
\hline Plaice & 1647 & 30.5 & 863 & 18.3 & 694 & 17.9 & 260 & 18.5 & 20 & 0 \\
\hline Flounder & 593 & 31.5 & 657 & 19.2 & 411 & 13.4 & 802 & 22.6 & 46 & 17.4 \\
\hline \multicolumn{11}{|c|}{1984} \\
\hline Cod & 4339 & 33.8 & 1621 & 40.1 & 1518 & 29.0 & 1503 & 26.3 & 355 & 7.0 \\
\hline Plaice & 1986 & 44.1 & 1381 & 34.4 & 2221 & 19.4 & 970 & 13.5 & 230 & 2.6 \\
\hline Flounder & 171 & 50.9 & 58 & 44.8 & 29 & 44.8 & 28 & 7.1 & 2 & 0 \\
\hline
\end{tabular}




\section{Occurrence of defective embryos}

Table 1 lists the total number of embryos and the percentage of those displaying aberrant development. In 1983 between $18 \%$ (cod) and $24 \%$ (plaice) of all eggs caught contained defective embryos; in 1984 this number was larger, ranging from $28 \%$ (plaice) to $44 \%$ (flounder). The early developmental stages usually showed the highest malformation rates (up to $51 \%$ in the case of flounder embryos in stage Ia in 1984); with progressive development, malformations decreased in numbers, being lowest in stage IV, prior to hatching (Table 2).

With regard to spatial distribution of aberrant embryos (Fig. 8), the highest rates of occurrence of malformations were recorded in the Mecklenburg Bight in 1983, particularly in the eastern part (Fig. 8a). The same pattern was found in 1984, even though the occurrence of pelagic eggs in the Mecklenburg Bight was very low (Fig. 8b). A second area with high incidence of malformation rates was located south and east of the island of Langeland. In 1983, increased incidence of malformations were also detected off the Eckernförde Bight (Fig. 8a). In the years 1983 and 1984, cod and plaice were equally affected throughout these areas (Figs 9,10 ). Highest malformation rates were found in stage Ia (Table 2).

The data base for the occurrence of aberrant flounder eggs was only large enough to allow evaluation in 1983. Except for the frequent occurrence of defective flounder embryos in the Flensburg Bight, no obviously high occurrences of malformations were registered for this species throughout the western Baltic.

\section{Incubation of eggs from plankton catches}

Incubation experiments were carried out to test the assumption that microscopically visible aberrations from normal embryo development cause pre-hatching death of the embryo or give rise to non-viable larvae. In these experiments, low hatching success coincided with high malformation rates as determined for the respective stations. Figure 11 shows an example of this correlation. For cod and plaice, the correlation was highly significant (cod: $r_{38}: 0.4656, p<0.01$; plaice: $r_{38}: 0.7258, p<0.01$ ), demonstrating the inverse correlation between higher observed malformation rates and lower rates of viable hatch.

\section{Egg mortality}

Mortality estimates for cod and plaice eggs were obtained for 1983 and 1984, calculating mortality for different stages as well as for the whole period of development. The instantaneous mortality rate (Z) per day was obtained using $\mathrm{N}_{\mathrm{t}} / \mathrm{N}_{\mathrm{o}}=\mathrm{e}^{-\mathrm{Zt}}$ (Harding \& Talbot, 1973; Bannister et al., 1974) where $N=$ number of eggs present at time $O\left(N_{o}\right)$ and at time $t\left(N_{t}\right) ; t=$ duration of stages Ia, Ib, II, III and IV from incubation experiments with Baltic eggs (Westernhagen, 1970). Total cod egg mortality for 1983 calculated on the basis of 19 stations (mean temp.: $2.1^{\circ} \mathrm{C} \pm 0.32$ ) was $99.18 \%$ through all stages, the instantaneous mortality rate $(Z)$ being 0.155 (Table 3 ). For 1984 the total mortality of cod eggs was estimated to be $96.39 \%$ with a $Z$ of only 0.0852 (calculated from 11 stations). Values for plaice in 1983 were: total egg mortality $99.79 \% ; Z=0.181$. For 1984 no consistent data on plaice egg mortality were available. 

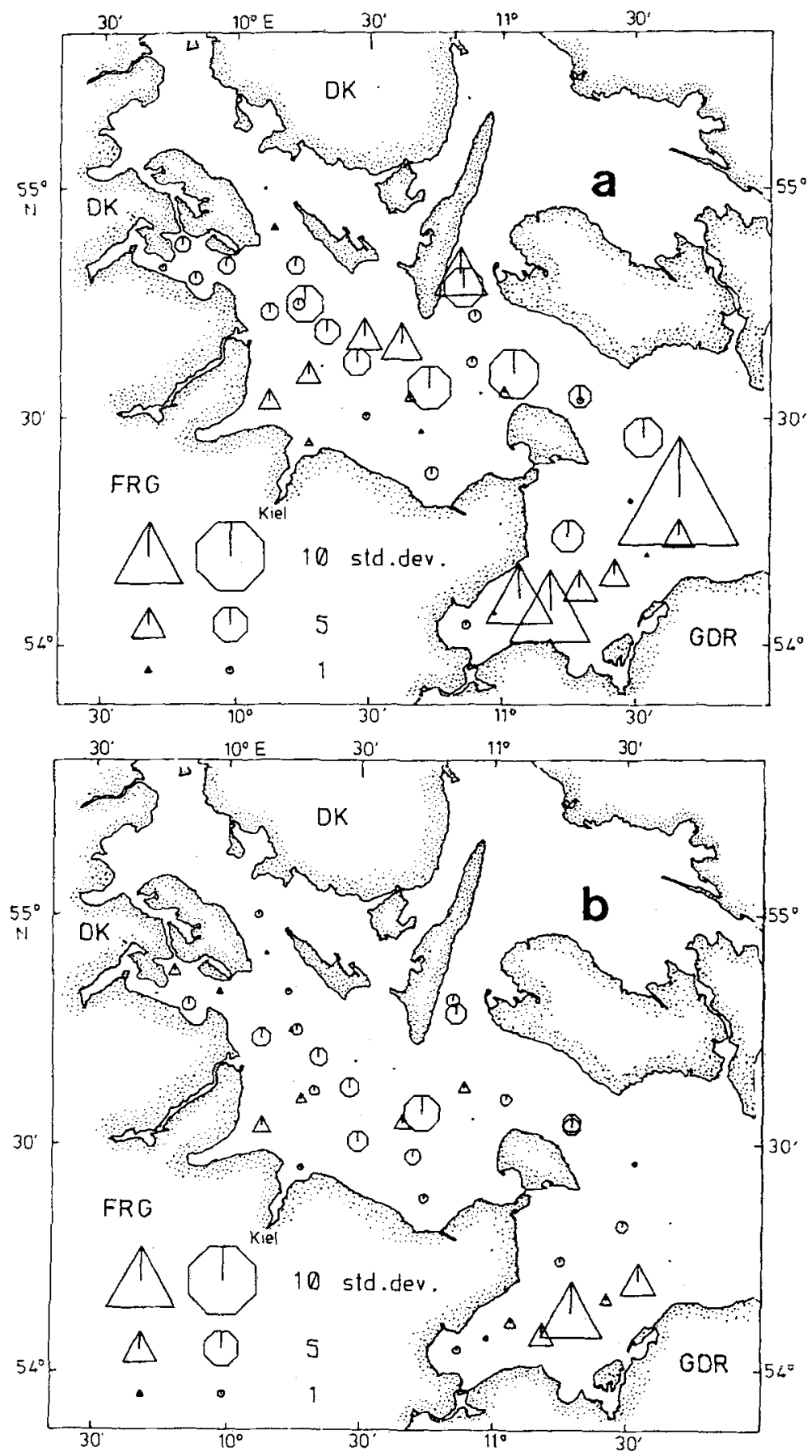

Fig. 8. Spatial distribution of the occurrence of aberrant fish embryos (cod, plaice, flounder) in the $\mathrm{S}=21 \times 10^{-3}$ layer in the westem Baltic in February/March 1983 (a) and 1984 (b). Triangles or hexagons indicate the $n$-fold deviation of the total relative frequency from the weighted mean of all embryos expressed in standard deviations (marked as bars in the symbols; triangles indicate aberration rate above weighted mean; hexagons indicate aberration rate below mean). A dot indicates total number of embryos below 20 

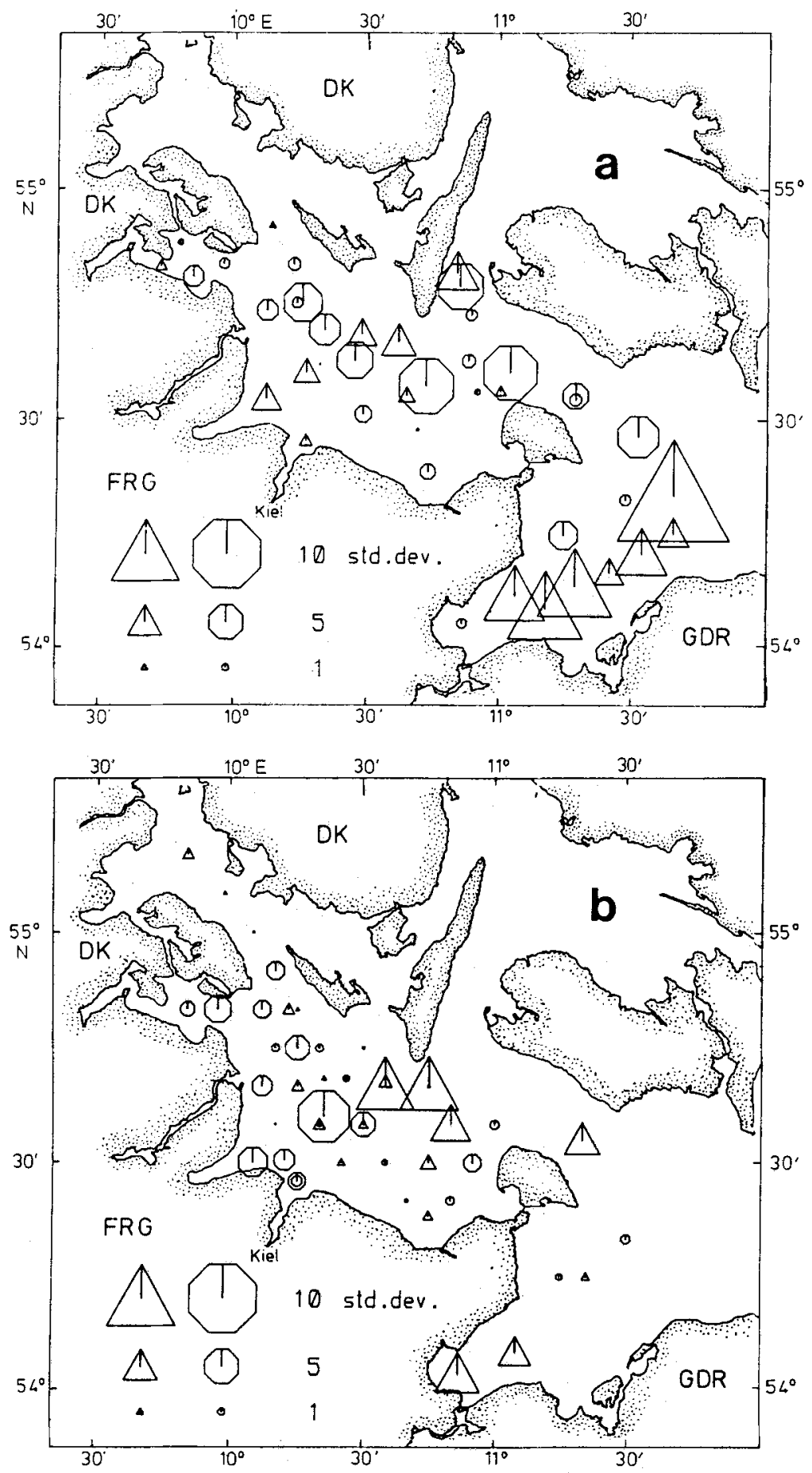

Fig. 9. Occurrence of aberrant cod (a) and plaice (b) embryos in the western Baltic, February/March 1983. For explanation of symbols see legend to Fig. 8 

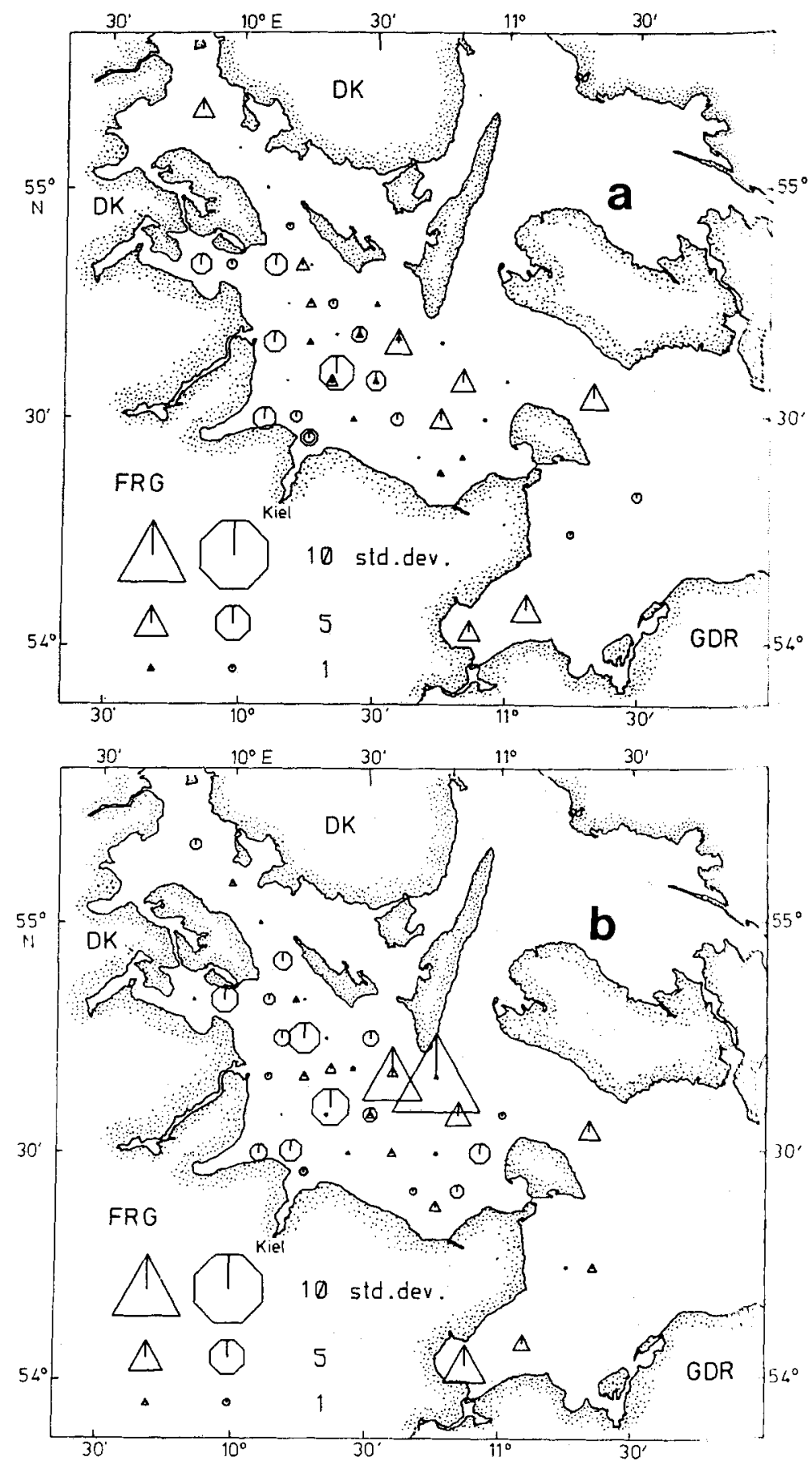

Fig. 10. Occurrence of aberrant cod (a) and plaice (b) embryos in the western Baltic, February/March 1984. For explanation of symbols see legend to Fig. 8 


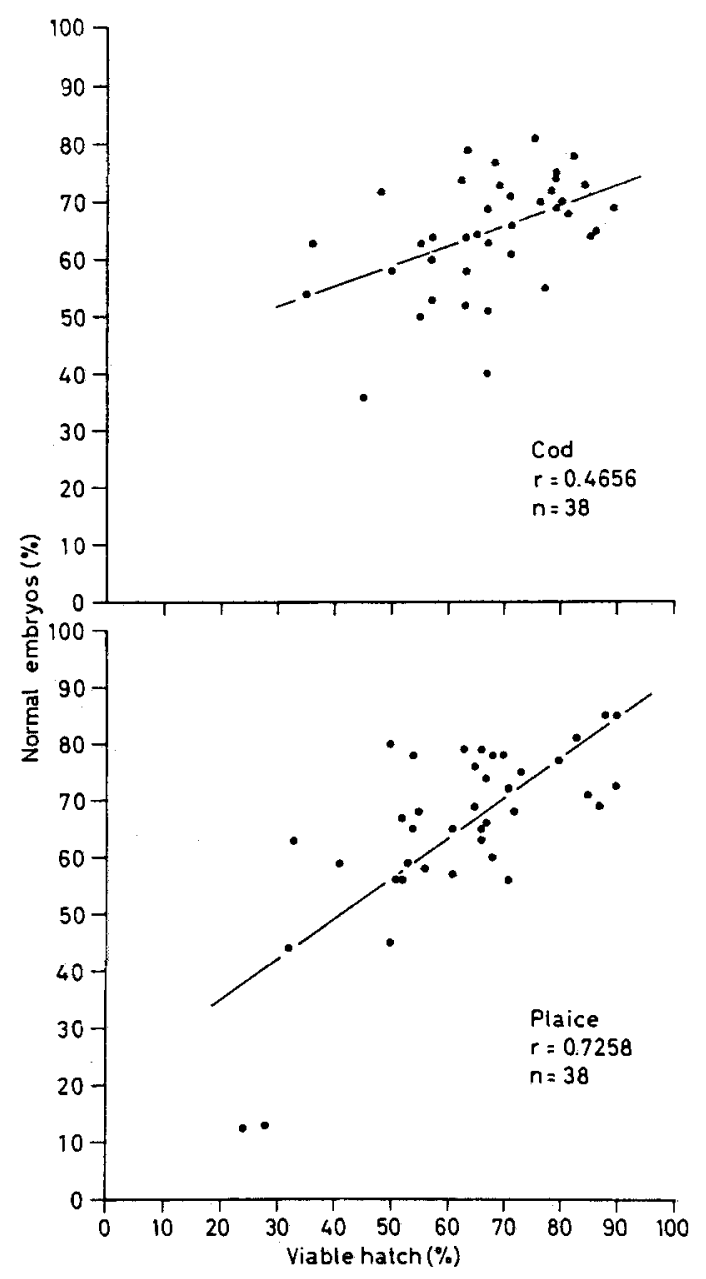

Fig. 11. Correlation between observed normal embryos in natural Baltic Sea egg populations from plankton catches and viable hatch (\%) determined experimentally from egg lots obtained in sequential tows at identical stations in February/March 1984 for cod and plaice

\section{DISCUSSION}

\section{Vertical distribution and abundance of eggs}

Regarding representativeness of the catches it has to be mentioned that a portion of the variability in the results could be attributed to variations in the depth strata covered by the plankton net. Inaccuracy of depth determination during sampling using length and angle of the towing wire led to the net frequently being towed deeper or shallower than intended. In addition, alteration in currents, towing speed and wind during ship operation caused the net to undulate through the water layer. This behavior of the net 
Table 3. Abundance, mortality and mortality rate estimates for planktonic eggs from the western Baltic. Temperature in the $\mathrm{S}=21 \times 10^{-3}$ layer: $2.1^{\circ} \mathrm{C}(1983) ; 1.18{ }^{\circ} \mathrm{C}(1984) . \mathrm{Z}=$ instantaneous mortality rate. $\mathrm{n}=$ total eggs from 19 stations ( $\operatorname{cod} 1983) ; 11$ stations ( $\operatorname{cod} 1984) ; 5$ stations (plaice 1983)

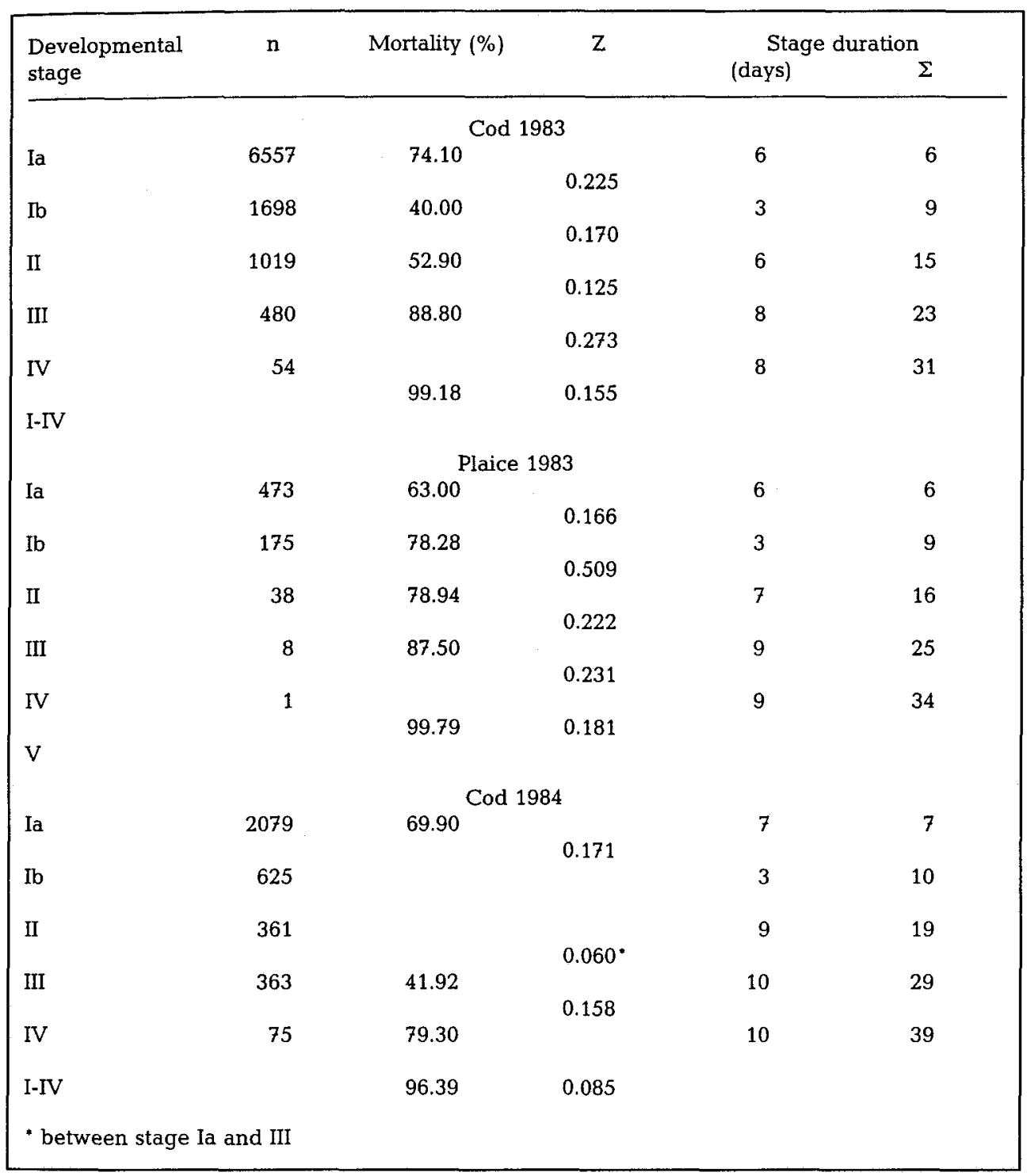

might have compensated for a potential sampling bias caused by species specific differences in buoyancy as well as the fact that eggs at advanced stages of development being slightly heavier than younger ones float in deeper water than the young stages. A possible total separation of the different developmental stages was prevented by the 
intensity of the halocline, which in the Baltic (Belt Sea) is known to be very pronounced (Siedler \& Hatje, 1974). Thus in 1983 the Sigma $T$ at several stations in the central western Baltic was around Sigma $T=5$ between $3 \mathrm{~m}$ and $5 \mathrm{~m}$ depth. At other depths horizons in the Mecklenburg Bight the Sigma $T$ at depths between $15 \mathrm{~m}$ and $18 \mathrm{~m}$ was above 6 . At a large Sigma $T$, eggs tend to be concentrated in a narrow layer just below the low salinity stratum. In contrast, in water bodies with less distinct or no salinity stratification, eggs are dispersed vertically over a wide depth range as has been described for the vertical distribution of mackerel eggs (Scomber scombrus; Coombs et al., 1981), eggs of sprat and pilchard (Sprattus sprattus, Sardina pilchardus) off Plymouth (Coombs et al., 1985) and of Atlantic halibut (Hippoglossus hippoglossus) in Norwegian waters (Haug et al., 1984).

On the other hand, sampling in a narrow discontinuity layer increases the risk of missing the egg-containing stratum. Hence the undulating path traced by the net may have increased the representativeness of the catches while it led to an underestimation of numerical egg abundance. In fact, abundance of eggs was low in the whole western Baltic, as compared to data from Kändler (1949) for a typical cod spawning area such as the Bornholm Basin. In the Bornholm Basin at the halocline, cod egg mean numbers of $10^{3}$ to $<10^{4}$ per $100 \mathrm{~m}^{3}$ have been observed (Müller \& Pommeranz, pers. comm.), while the highest number of eggs caught during the present investigation was around 200 eggs per $100 \mathrm{~m}^{3}$ (Figs 2, 5). Even though the grounds around the Vejsnäs Trough are considered to be the main spawning grounds for western Baltic cod (Kändler, 1949; Thurow, 1970), and egg concentrations in the general area were elevated (Fig. 3) no pronounced peak in egg numbers was detected. This is in contrast with results obtained by Kändler (1949) during the egg surveys between 1925 and 1938, where egg numbers of more than $300 \cdot \mathrm{m}^{-2}$ had been observed. During the present study, cod eggs were distributed in numbers of more than 50 per $100 \mathrm{~m}^{3}$ throughout the entire area west of the island of Fehmarn without pronounced peak occurrences. Presence of pelagic eggs was generally dependent on the existence of a high salinity $\left(>20 \times 10^{-3}\right)$ layer. In 1984 , when bottom water salinity was low in the Mecklenburg Bight and in the Fehmarn Belt, the occurrence of pelagic fish eggs was low in these parts and was confined to locations where isolated water bodies of salinity higher than $\mathrm{S}=20 \times 10^{-3}$ persisted (Fig. 5; cf. also Krenkel, 1981). These findings are consistent with observations made by Kändler (1949) on cod egg abundance in the Mecklenburg Bight and the work of Thurow (1970) who concluded, that even though indigenous spawning of cod may occur in the Mecklenburg Bight, overall intensity is low. The occurrence of indigenous spawning in the Mecklenburg Bight in 1983 is supported by the fact that the majority of eggs from this area (up to $93 \%$ in cod and $95 \%$ in plaice) was in the very first cleavage stages (Ia). Hence they must have been spawned only recently in this area.

As February/March is the main spawning season for cod in the western Baltic (Hensen, 1884; Strodtmann, 1906; Ehrenbaum \& Strodtmann, 1904; Thurow, 1970), most of the cod eggs were at early developmental stages. The peak spawning season for plaice is somewhat earlier than that for cod (cf. also Oray, 1965), i.e. in January, which was documented by the preponderance (1984) or relatively high abundance (1983) of older developmental stages of this species in the plankton catches (Table 2).

The unexpected low numbers of pelagic flounder eggs in the water column corresponded with an observation made in 1984 . In an incubation experiment $\left(6^{\circ} \mathrm{C}\right)$ conducted 
with 67 pairs of flounders caught in the Kiel Bight, of 67 successfully fertilized and developing egg lots (67 females $\times 67$ males) only 44 produced eggs that floated at a salinity of $S=25 \times 10^{-3}$. This phenomenon was unusual, since at this salinity/temperature combination water density is around 20.8 , which from previous investigations should allow flounder eggs to float.

Vertical distribution of eggs followed that observed by Kändler \& Tan (1965) for pelagic fish eggs in the western Baltic. Cod, plaice and flounder eggs were found mainly in the $21 \times 10^{-3}$ layer, which is typical for western Baltic pelagic fish eggs. Eggs from the eastern part of the Baltic still float at salinities of $16 \times 10^{-3}$ and lower (Strodtmann, 1906; Kändler \& Tan, 1965) since egg density does vary in relation to the salinity to which the adults are acclimated. This does not imply total absence of eggs from these stations, because former investigations (Hensen, 1884; Strodtmann, 1906; Mielck \& Künne, 1935; Kändler, 1949) have shown that eggs could be found lying on the bottom when there was no high salinity to support pelagic eggs. Such eggs escape detection by the sampling method employed.

\section{Occurrence of defective embryos and egg mortality}

The prevalence of defective embryos was about $20 \%$ of the total in 1983 and roughly $30 \%$ in 1984. Earlier stages showed higher rates of developmental failure than more advanced stages (Table 2). In flounder embryos up to $51 \%$ of the earliest stage (Ia) were affected. Hence differential mortality may lead to a greater reduction in the incidence of visibly affected embryos. Throughout development a large percentage of the abnormal embryos in stage Ia die off before reaching a later stage, thus the rate of visibly affected embryos decreases in the course of further development.

There is little information available on the prevalence of developmental failures in naturally occurring fish embryos. Yannopoulos \& Yannopoulos (1981) described malformations in the eggs of Sardina pilchardus and Engraulis enchrasicolus with ensuing embryo mortality for the Saronikos Gulf in the Aegean Sea. Up to $11.6 \%$ (S. pilchardus) and $9.2 \%$ (E. enchrasicolus) suffered from malformations. Although the authors speculated on climatic causes, no adequate explanation for this phenomenon could be given. For the Baltic from the Bornholm area to the Gulf of Finland, Grauman (1986) observed the occurrence of abnormal cod and sprat embryos in the years 1979 to 1982 in the advanced stages II-III. The mean incidence of abnormal embryos was $36 \%$; in sprat eggs, $25 \%$ of all embryos were malformed. Grauman (1986) observed malformations in eggs particularly in later (II-III) stages and described severe morphological anomalies such as curvature of the body axis, twinning and body disproportions as the most common phenomena. Grauman (1986) discussed pollution of the Baltic (oil pollution) as a potential reason for the high malformation rates observed.

Looking at the spatial distribution of malformation rates during our studies (Fig. 8a, b) we notice that in both years centres of high prevalences of malformations occurred in the Mecklenburg Bight and south of the island of Langeland. In 1983, additional centres were located off the Eckernförde Bight and east of the island of Langeland. Either natural or man-made factors may be responsible for the occurrence of considerable amounts of defective fish embryos. Among natural factors, physical parameters such as temperature, salinity and oxygen may be suspected to cause embryonic abnormalities. Several investi- 
gations have shown that low salinity and high temperature (Westernhagen, 1968, 1970, 1974; Forrester \& Alderdice, 1966; Alderdice \& Forrester, 1968, 1971), or low oxygen (Braum, 1973) may cause considerable aberrations or death in developing fish embryos. Dead pelagic fish embryos have been frequently recorded from plankton catches in the Baltic (Apstein, 1911; Heinen, 1912; Kändler, 1938) and Heinen (1912) suggested that low salinity $\left(7.15 \times 10^{-3}\right)$ caused the death of the embryos. However, these reports should be taken with considerable caution: dead eggs do not float; only unfertilized eggs at low temperatures may float for several days. In addition, as a result of high sensitivity to mechanical damage embryos are likely to die from injuries afflicted in the process of catching [cf. Southward \& Demir (1974), the towing speed being $>4 \mathrm{kn}$ ]. Results obtained by Rollefsen (1932) on cod egg susceptibility to mechanical stress lead to the same conclusions.

In the present study, low salinity is unlikely to have caused the high rates of observed abnormalities, as salinity of the water from which the eggs were taken was usually between 20 and $21 \times 10^{-3}$ (towing level of net). Whenever this salinity was not reached, the lowest value measured was $S=17.5 \times 10^{-3}$. For the incubation of Baltic cod and plaice eggs, $20 \times 10^{-3}$ is the optimum salinity and at $17.5 \times 10^{-3}$ viable hatch is not adversely affected (Westernhagen, 1970). Besides, the station with the lowest salinity $\left(17.5 \times 10^{-3}\right)$ which still yielded eggs had a low rate of malformations (3.5 SD below the mean). The fact that malformation rates in fish eggs from the North Sea also are high (Dethlefsen et al., 1985) compared to those from the Baltic excludes the possibility that low salinity is a major cause for malformations in embryos from the Baltic.

High temperatures, known to cause malformations in marine winter spawners, are well above those $\left(>8^{\circ} \mathrm{C}\right)$ recorded in winter in the Baltic $\left(1^{\circ}-2{ }^{\circ} \mathrm{C}\right)$. Thus temperature was not likely to have caused the observed malformations.'

Oxygen concentrations in the open water column of the Belt Sea in spring do not drop to biologically critical levels below $2 \mathrm{ml}^{-1^{-1}}$ (Reimers, 1976), and even in the deeper areas of the Arkona deep ( $>40 \mathrm{~m}$ ) from January to March oxygen concentrations are between 4.6 and $6.4 \mathrm{ml} \cdot \mathrm{l}^{-1}$ (Engström \& Fonselius, 1983), levels which allow normal development in teleosts (Braum, 1973). Thus other causes for defective development must be sought.

Man-made pollutants remain as potential factors that could contribute to the observed malformations in pelagic fish eggs. Pollutants may act in two ways on the embryo: (1) through accumulation of toxicants in the parental gonads and (2) by effects on the embryo through the incorporated substances. Westernhagen et al. (1981) have shown that the first possibility may occur in Baltic flounder, whose gonads had a high PCB burden. Viable hatch from these gonads was low $(<50 \%)$ due to faulty development of embryos and high embryo mortality. Similar effects are known from Baltic herring, Clupea harengus (Hansen et al., 1985), striped bass, Dicentrarchus labrax (Westin et al., 1985) and North Sea whiting, Merlangius merlangus (Cameron et al., 1986).

Another mode of effect may be through the impact of pollutants in the water directly on the embryo. Yet levels of pollutants actually present in the water column, particularly chlorinated hydrocarbons (Brügmann \& Luckas, 1978), are considered too low to cause acute effects on embryo survival (cf. Westernhagen, 1988). Such low levels, to be active, could act through biomagnification. If this is accepted, then the spatial distribution of 
malformations involving at least the two areas - south of the island of Langeland and the Mecklenburg Bight - (Figs 8, 9, 10) in the western Baltic, calls for detailed investigation of the reasons for this phenomenon. The question then arises: what are the connections between parental fish and the regional distribution of eggs and malformed embryos?

\section{Migratory activities and currents}

Investigations of Bagge (1961), Berner (1968) and Thurow (1970) show that the spawning stock of cod in the Kiel Bight is highly stationary and no pronounced spawning migration takes place. Currents in the Western Baltic are more of a regional, small-scale character, induced by local wind forces (Dietrich \& Schott, 1974; Siedler \& Hatje, 1974), and large-scale transportation through the Belts is limited to surface water.

Thus, the eggs collected in the south-eastern part of the Kiel Bight must originate from spawners of that area, plus those immigrating from the Mecklenburg Bight (Thurow, 1970). Embryos from the north-eastern part of the area were generally in better condition than those from the south-eastern waters. Since the main water movements in the Baltic are characterized by inflowing deep water of high salinity and outflowing surface waters of low salinity (Dietrich \& Schott, 1974), we believe that a considerable part of the egg population north-east of the Langeland-Kiel transect (Figs 8, 9, 10) could have been transported by high salinity water from the less polluted waters of the Kattegat into the Baltic, since eggs of the species under question from the North Sea show a lower prevalence of malformations than those from the Baltic (Dethlefsen et al., 1985, 1986). The implication of the spatial distribution of malformation rates in the Baltic is not clear but it does not contradict the theory that spawners from the Kiel Bight produce more malformed embryos due to bioaccumulated pollutants than found in the inflowing waters from the Kattegat. Malformation rates noted in the area south of Langeland may be particularly high due to the fact, that this area is a major spawning ground, and malformation rates in freshly spawned eggs (early development) are always found to be higher than in later stages. A similar situation prevails in the Mecklenburg Bight, suggesting that the parental fish from both regions produce "poor quality" eggs, probably due to pollution. This question needs to be examined in more detail, employing specially designed incubation experiments with parental fish from selected areas in conjunction with chemical residue analysis.

\section{Effects on recruitment}

From preliminary experiments with defective embryos from the North Sea we know that the malformations observed were to a large extent $(85 \%)$ lethal (Westernhagen, unpublished data). The question then arises whether defective embryonic development may add significantly to natural mortality in the field, even to the extent that recruitment might be affected. We recall that total mortality during the embryonic phase, estimated on the basis of observed changes in proportions of the successive developmental stages, was $99.18 \%$ in cod and $99.79 \%$ in plaice for 1983 and $96.39 \%$ for cod in 1984 . These figures are nearly identical to those determined by Wieland (1987) for cod eggs in the Bornholm Deep. Figures reported by Harding \& Talbot (1973) and Bannister et al. (1974) for the eggs of North Sea plaice (1962-1971) were considerably lower (ca 50-80\%) than 
those we determined for the Baltic in $1983(99.79 \%)$. High rates of natural egg mortality are known also for other marine species such as North Sea sole, Solea solea $(97.35 \%$ at $13.09{ }^{\circ} \mathrm{C}$; Riley, 1974) or Pacific sardine, Sardinops caerulea (95\%; Ahlstrom, 1954).

Assuming natural mortality to be generally high, and considering for argument's sake that the defective embryos for 1983 and 1984 were normal, would increase survival rates for cod by $22.0 \%$ (1983) or $33.8 \%$ (1984) (Table 2) giving a total egg survival of $1.06 \%$ in 1983 (instead of $0.82 \%$ ) and $5.45 \%$ in 1984 instead of $3.61 \%$ (see Table 3). These increases are probably too small (in terms of biological significance) to cause a detectible impact on recruitment (the high mortality in the larval phase not having been considered). In North Sea plaice, for example, differences of several orders of magnitudes in egg and larvae numbers between year classes are known to be required to cause a measurable impact on recruitment (Bannister et al., 1974). We suspect that the particularly low egg mortality occurring in 1963 (around $50 \%$ ), probably in conjunction with good larval survival, could have been responsible for the generation of a strong year class.

On the other hand, current overfishing of the economically most important species in the western and central Baltic (Tiews, 1986; Weber, 1987) (exception at present: herring) has lead to a severe depletion of stocks, especially cod, and it is feared that spawning stock size has been noticeably reduced (Tiews, 1986). Thus even a small impact on larvae production, as demonstrated during the present study - insignificant in an unstressed fish population - may in the case of the overexploited Baltic stocks eventually lead to reduced recruitment.

\section{Defective embryos as a monitoring tool}

The occurrence of large numbers of defective embryos in the sea may be considered an abnormal phenomenon that has arisen only in the near past due to increasing anthropogenic input into the sea. Earlier investigators such as Strodtmann (1906), Jacobsen \& Johansen (1908), Heinen (1912), Mielck \& Künne (1935) and others probably would have noticed above-normal defective egg development rates, particularly in the early stages. The only information available from the past is the relatively large number of dead eggs in plankton hauls as for example reported by Apstein (1911), Heinen (1912), Rollefsen (1930) and Pommeranz (1973), but as mentioned earlier we consider this an artifact due to fast towing $(5 \mathrm{kn}$; Pommeranz, 1973) or other faulty handling. Thus, unfortunately, no systematic records exist of in situ abnormal egg development from former years.

Information on defective egg mortality in naturally spawned eggs in the sea is provided by the recent investigations of Graumann (1986) from the Baltic and our own work (Dethlefsen et al., 1985, 1986) from the North Sea. These studies report high prevalence of irregular or defective embryo development. For the North Sea, areas with high rates of malformations (up to $50 \%$ in whiting embryos) were located off the mouths of the Rhine and Elbe rivers, both highly polluted areas, and in the vicinity of the German and Dutch dumping areas for wastes from $\mathrm{TiO}_{2}$ production.

Investigations in the New York Bight (Longwell \& Hughes, 1981; Longwell et al., 1984 ) on the occurrence of gross embryo malformations in the eggs of Atlantic mackerel (Scomber scombrus) eggs also demonstrated a high correlation between abnormal egg development (including cytogenetic aberrations) and pollution of surface waters. These 
authors stressed the usefulness of fish eggs for measuring sublethal effects of pollution on reproduction in the field. In their material, aside from the physical parameter salinity, aromatic hydrocarbons and chlorinated compounds in the water mass acted as primary variables associating with all developmental stages of mackerel embryos (Chang \& Longwell, 1984), influencing the occurrence of malformations and cytogenetic abnormalities.

Therefore, it appears that occurrence of developmental abnormalities in developing fish embryos in areas free of extreme hydrographical conditions may serve as an indication of the state of the marine environment. This is likely to be so, provided the hydrographical situation in the area under question allows for the interpretation of the origin of water bodies, and the migratory activities of spawning populations are well understood. For monitoring studies, and for the examination of the potential correlation between observed incidence of malformations and environmental pollution load, simultaneous chemical analyses of embryos or gonads of parental fish from the respective area are desired. For optimization of the method, the standardization of sampling procedures and the assessment of embryonic malformations should be given further attention.

This article contains parts of a doctoral study by P. Cameron in the Faculty of Biology, Hamburg University.

\section{LITERATURE CITED}

Ahlstrom, E. H., 1954. Pacific sardine (pilchard) eggs and larvae, and other fish larvae, Pacific coast, 1952. - Spec. scient. Rep. U.S. Fish. Wildl. Serv. 123, 1-76.

Alderdice, D. F. \& Forrester, C. R., 1968. Some effects of salinity and temperature on early development and survival of the English sole (Parophrys vetulus). - J. Fish. Res. Bd Can. 25, 495-521.

Alderdice, D. F. \& Forrester, C. R., 1971. Effects of salinity, temperature, and dissolved oxygen on early development of the Pacific cod (Gadus macrocephalus). - J. Fish. Res. Bd Can. 28, 883-902.

Apstein, C., 1911. Die Verbreitung der pelagischen Fischeier und Larven in der Beltsee und den angrenzenden Meeresteilen 1908/09. - Wiss. Meeresunters. (Abt. Kiel) 13, 225-284.

Bagge, O., 1961. Märkning af torsk i indre Danske Garvande. - FiskUnders. Kopenhagen 1960, 21, 10-22 (from Thurow, 1970).

Bannister, R. C. A., Harding, D. \& Lockwood, S. L., 1974. Larval mortality and subsequent year-class strength in the plaice (Pleuronectes platessa). In: The early life history of fish. Ed. by J. H. S. Blaxter, Springer, Berlin, 21-37.

Beamish, R. J. \& Harvey, H. H., 1972. Acidification of the La Cloche mountain lakes, Ontario, and resulting fish mortalities. - J. Fish. Res. Bd Can. 29, 1131-1143.

Berner, M., 1968. Dorschmarkierungen in der Mecklenburger Bucht im Jahre 1965. - Fisch.-Forsch. $6,73-76$.

Braum, E., 1973. Einflüsse chronischen exogenen Sauerstoffmangels auf die Embryogenese des Herings (Clupea harengus). - Neth. J. Sea Res. 7, 363-375.

Brügmann, L. \& Luckas, B., 1978. Zum Vorkommen von polychlorierten Biphenylen und DDTMetaboliten im Plankton und Wasser der Ostsee. - Fisch.-Forsch. 16, 31-37.

Burdick, G. E., Harris, E. J., Dean, H. J., Walker, T. M., Skea, J. \& Colby, D., 1964. The accumulation of DDT in lake trout and the effect on reproduction. - Trans. Am. Fish. Soc. 93, 127-136.

Burdick, G. E., Harris, E. J., Skea, J., Karched, R. \& Frisia, C., 1972. Effect of rate and duration of feeding DDT on the reproduction of salmonid fishes reared and held under controlled conditions. - N. Y. Fish Game J. 19, 97-115.

Cameron, P., Westernhagen, H. von, Dethlefsen, V. \& Janssen, D., 1986. Chlorinated hydrocarbons in North Sea whiting (Merlangius merlangus) and effects on reproduction. - C. M./ICES, E25, $1-10$. 
Chang, S. \& Longwell, A., 1984. Examining statistical associations of malformation, cyto-pathology and cytogenetic abnormality of Atlantic mackerel embryos with indicator levels on environmental contaminants in the New York Bight. - C. M./ICES, E11, 1-9.

Coombs, S. H., Pipe, R. K. \& Mitchell, C. E., 1981. The vertical distribution of eggs and larvae of blue whiting (Micromesistius poutassou) and mackerel (Scomber scombrus) in the eastern North Atlantic and North Sea. - Rapp. P.-v. Réun. Cons. int. Explor. Mer 178, 188-195.

Coombs, S. H., Fosh, C. A. \& Keen, M. A., 1985. The buoyancy and vertical distribution of eggs of sprat (Sprattus sprattus) and pilchard (Sardina pilchardus). - J. mar. biol. Ass. U. K. 65, 461-474.

Dannevig, A., 1945. Undersökelser i Oslofjorden 1936-1940. Egg og yngel av vergytende fiskearter. - FiskDir. Skr. (Ser. Havunders.) 8, 1-91.

Dethlefsen, V., Cameron, P. \& Westernhagen, H. von, 1985. Untersuchungen über die Häufigkeit von Mißbildungen in Fischembryonen der südlichen Nordsee. - Infn Fischw. 32, 22-27.

Dethlefsen, V., Cameron, P., Westernhagen, H. von \& Janssen, D., 1986. Morphologische und chromosomale Untersuchungen an Fischembryonen der südlichen Nordsee in Zusammenhang mit der Organochlorkontamination der Elterntiere. - Veröff. Inst. Küst.- u. Binnenfisch. 96, 1-57.

Dietrich, G. \& Schott, F., 1974. Wasserhaushalt und Strömungen. In: Meereskunde der Ostsee. Hrsg. von L. Magaard \& G. Rheinheimer. Springer, Berlin, 33-41.

Ehrenbaum, E. \& Strodtmann, S., 1904. Eier und Jugendformen der Ostseefische. - Arb. dt. wiss. Kommn int. Meeresforsch. 6, 61-126.

Engström, S. G. \& Fonselius, S. H., 1986. Observations in the deep basins of the Baltic in 1983. Annls biol. Copenh. 40,54-59.

Forrester, C. R. \& Alderdice, D. F., 1966. Effects of salinity and temperature on embryonic development of the Pacific cod (Gadus macrocephalus). - J. Fish. Res. Bd Can. 23, 319-340.

Graumann, G. B., 1986. Morphological anomalies in the Baltic sea fishes at early stages of ontogenesis. Symp. ecol. Invest. Baltic Sea Environ. (Ekologija Baltijskogo morja) Gidrometoizdat., Leningrad, 282-291.

Haines, T. A., 1981. Acidic precipitation and its consequences for aquatic ecosystems: a review. Trans. Am. Fish. Soc. 110, 669-707.

Hansen, P.-D., Westernhagen, H. von \& Rosenthal, H., 1985. Chlorinated hydrocarbons and hatching success in Baltic herring spring spawners. - Mar, environ. Res. 15, 59-76.

Harding, D. \& Talbot, J. W., 1973. Recent studies on the eggs' and larvae of the plaice Pleuronectes platessa in the Southern Bight. - Rapp. P.-v. Réun. cons. int. Explor. Mer 164, 261-269.

Harvey, H. \& Lee, C., 1982. Historical fisheries changes related to surface water pH changes in Canada. In: Acid rain/fisheries. Ed. by R. Johnson. Northeastern Division, Am. Fish. Soc., Bethesda, Maryland, 45-55.

Haug, T., Kjörsvik, E. \& Solemdal, P., 1984. Vertical distribution of Atlantic halibut (Hippoglossus hippoglossus) eggs. - Can. J. Fish. aquat. Sci. 41, 798-804.

Heinen, A., 1912: Die planktischen Fischereier und Larven der Ostsee. - Wiss. Meeresunters. (Abt. Kiel) 14, 129-189.

Hensen, V., 1884. Über das Vorkommen und die Menge der Eier einiger Ostseefische, insbesondere derjenigen der Scholle, der Flunder, des Dorsches. - Ber. Kommn Unters. dt. Meere Kiel 7-9, 299-313.

Jacobsen, J. P. \& Johansen, A. C., 1908. Remarks on the changes in specific gravity of pelagic fish eggs and the transportation of some in Danish waters. - Medd. Kommn Havunders. 3, 3-24.

Kändler, R., 1938. Untersuchungen über das Laichen des Ostseedorsches im Herbst. - Kieler Meeresforsch. 2, 271-292.

Kändler, R., 1949. Untersuchungen über den Ostseedorsch während der Forschungsfahrten mit dem R.F.D. "Poseidon" in den Jahren 1925-1938. - Ber. dt. wiss. Kommn Meeresforsch. 11, 137-245.

Kändler, R., 1958. German observations on the hydrography of the Belts and the Baltic in 1956. Annls biol. Copenh. 13, 100.

Kändler, R. \& Tan, E., 1965. Investigations on the osmoregulation in pelagic eggs of gadoid flatfishes in the Baltic. Part. I. Changes in volume and spec. gravity at different salinities. - C. M./ICES E43, 1-5.

Krenkel, K., 1981. Über das Vorkommen der Eier und Larven von Sprott (Sprattus sprattus) und Dorsch (Gadus morhua) in der Ostsee in den Jahren 1977-1980. - Fisch.-Forsch. 19, 31-36.

Longwell, A. C. \& Hughes, J. B., 1981. Cytologic, cytogenetic and developmental state of Atlantic 
mackerel eggs from sea surface water of the New York Bight, and prospects for biological effects monitoring with ichthyoplankton. - Rapp. P.-v. Réun. Cons. int. Explor. Mer 179, 275-291.

Longwell, A. C., Perry, D., Hughes, J. \& Hebert, A., 1984. Embryological, cyto-pathological and cytogenetic analyses of ' $74,{ }^{\prime} 77$ and '78 planktonic A'tlantic mackerel eggs in the New York Bight. - C. M./ICES, E13, 1-8.

Mielck, W. \& Künne, C., 1935. Fischbrut- und Planktonuntersuchungen auf dem Reichsforschungsdampfer "Poseidon" in der Ostsee, Mai-Juni 1931. - Wiss. Meeresunters (Abt. Helgoland) 19, 4-120.

Oray, I., 1965. Über die Verbreitung der Fischbrut in der südlichen Nordsee und im östlichen englischen Kanal im Winter. - Ber. dt. wiss. Kommn Meeresforsch. 18, 79-106.

Peakall, D. B., 1970. Pesticides and the reproduction of birds. - Scient. Am. 222, 73-78.

Pommeranz, T., 1973. Das Vorkommen von Fischeiern, insbesondere von Eiern der Scholle (Pleuronectes platessa L.), in den oberflächennahen Wasserschichten der südlichen Nordsee. Ber. dt. wiss. Kommn Meeresforsch. 22, 427-444.

Ratcliffe, D. A., 1970. Changes attributable to pesticides in egg breakage frequency and eggshell thickness in some British birds. - J. appl. Ecol. 7, 67-107.

Reimers, T., 1976. Anoxische Lebensräume: Struktur und Entwicklung der Mikrobịozönose an der Grenzfläche Meer/Meeresboden. - Rep. Sonderf.Ber. 95 (Wechselwirkung Meer-Meeresboden) Univ. Kiel 20, 1-134.

Riley, J. D., 1974. The distribution and mortality of sole eggs (Solea solea [L.]) in inshore areas. In: The early life history of fish. Ed. by H. S. Blaxter. Springer, Berlin, 39-52.

Rollefsen, G., 1930. Observations on cod eggs. - Rapp. P.-v. Réun. Cons. perm. int. Explor. Mer. 65, 31-34.

Rollefsen, G., 1932. The susceptibility of cod eggs to external influences. - J. Cons. perm. int. Explor. Mer. 7, 367-373.

Sevaldrud, I. H., Muniz, I. P. \& Kalvenes, S., 1980. Loss of fish populations in southern Norway, dynamics and magnitude of the problem. - Proc. Int. Conf. ecol. Impact Acid precip., Norway, 1980, SNSF Project, 350-351.

Siedler, G. \& Hatje, G., 1974. Temperatur, Salzgehalt und Dichte. In: Meereskunde der Ostsee. Hrsg, von L. Magaard \& R. Rheinheimer. Springer, Berlin, 43-60.

Southward, A. J. \& Demir, N., 1974. Seasonal changes in dimensions and viability of the developing eggs of the Cornish pilchard (Sardina pilchardus Walbaum) off Plymouth. In: The early life history of fish. Ed. by J. H. S. Blaxter. Springer, Berlin, 53-68.

Spies, R. B., Rice, D. W., Montagna, P. A. \& Ireland, R. R., 1985. Reproductive success, xenobiotic contaminants and hepatic mixed-function oxidase (MFO) activity in Platichthys stellatus populations from San Francisco Bay. - Mar. environ. Res. 17, 117-121.

Strodtmann, S., 1906. Laichen und Wandern der Ostseefische. - Wiss. Meeresunters. (Abt. Helgoland) 7, 133-216.

Thurow, F., 1970. Über die Fortpflanzung des Dorsches Gadus morhua (L.) in der Kieler Bucht. - Ber. dt. wiss. Kommn Meeresforsch. 21, 170-192.

Tiews, K., 1986. Dorschfangmöglichkeiten im Bornholm Becken und südlichen Gotlandbecken werden schlechter. - Infn Fischw. 33, 15-16.

Weber, W., 1987. Der Dorschbestand der westlichen Ostsee braucht dringend Schonung. - Infn Fischw. 34, 74-75.

Westernhagen, H, von, 1968. Versuche zur Erbrütung der Eier des Schellfisches (Melanogrammus aeglefinus L.) unter kombinierten Salzgehalts- und Temperaturbedingungen. - Ber. dt. wiss. Kommn Meeresforsch. 19, 270-287.

Westernhagen, H. von, 1970. Erbrütung der Eier von Dorsch (Gadus morhua), Flunder (Pleuronectes flesus) und Scholle (Pleuronectes platessa) unter kombinierten Temperatur- und Salzgehaltsbedingungen. - Helgoländer wiss. Meeresunters. 21, 21-102.

Westernhagen, H. von, 1974. Incubation of garpike eggs (Belone belone Linné) under controlled temperature and salinity conditions. - J. mar. biol. Ass. U. K. 54, 625-634.

Westernhagen, $H$. von, 1988. Sub-lethal effects of pollutants on fish eggs and larvae. In: Fish physiology. Ed. by W. S. Hoar \& D. J. Randall. Acad. Press, New York, 11A, 253-346.

Westermhagen, H. von, Rosenthal, H., Dethlefsen, V., Ernst, W., Harms, U. \& Hansen, P.-D., 1981. 
Bioaccumulating substances and reproductive success in Baltic flounder Platichthys flesus. Aquat. Toxicol. 1, 85-99.

Westernhagen, H. von, Sperling, K.-R, Janssen, D., Dethlefsen, V., Cameron, P., Kocan R., Landolt, M., Fürstenberg, G. \& Kremling, K., 1987. Anthropogenic contaminants and reproduction in marine fish. - Ber. Biol. Anst. Helgoland, 3, 1-70.

Westin, D. T., Olney, C. E. \& Rogers, B. A., 1985. Effects of parental and dietary organochlorines on survival and body burdens of striped bass larvae. - Trans. Am. Fish. Soc. 114, 125-136.

Whipple, J., Eldridge, M., Benville, P., Bowers, M., Jarvis, B. \& Stapp, N., 1981. The effect of inherent parental factors on gamete condition and viability in striped bass (Morone saxatilis). - Rapp. P.-v. Réun. Cons. int. Explor. Mer. 178, 93-94.

Wieland, K., 1987. Untersuchungen zur Sterblichkeit von Dorscheiern im Bornholmbecken. Dipl. Arb., Univ. Kiel, 97 pp.

Yannopoulos, A. \& Yannopoulos, C., 1981. Fish egg mortality and abnormal embryogenesis. - Rapp. P.-v. Réun. int. Explor. scient: Mer Mediterr. 27 (5), 143-146. 